\title{
Investigating fluorescent organic matter composition as a key predictor for arsenic mobility in groundwater aquifers
}

Schittich, Anna-Ricarda; Wünsch, Urban; Kulkarni, Harshad; Battistel, Maria; Bregnhøj, Henrik; Stedmon, Colin ; McKnight, Ursula S.

\section{Published in:}

Environmental Science and Technology

Link to article, DOI:

10.1021/acs.est.8b04070

Publication date:

2018

Document Version

Peer reviewed version

Link back to DTU Orbit

Citation (APA):

Schittich, A-R., Wünsch, U., Kulkarni, H., Battistel, M., Bregnhøj, H., Stedmon, C., \& McKnight, U. S. (2018). Investigating fluorescent organic matter composition as a key predictor for arsenic mobility in groundwater aquifers. Environmental Science and Technology, 52(22), 13027-13036. https://doi.org/10.1021/acs.est.8b04070

\section{General rights}

Copyright and moral rights for the publications made accessible in the public portal are retained by the authors and/or other copyright owners and it is a condition of accessing publications that users recognise and abide by the legal requirements associated with these rights.

- Users may download and print one copy of any publication from the public portal for the purpose of private study or research.

- You may not further distribute the material or use it for any profit-making activity or commercial gain

- You may freely distribute the URL identifying the publication in the public portal 


\section{Investigating fluorescent organic matter composition as a key predictor for arsenic mobility in groundwater aquifers \\ Anna-Ricarda Schittich, Urban Wünsch, Harshad Kulkarni, Maria Battistel, Henrik Bregnhøj, Colin Andrew Stedmon, and Ursula Solard McKnight}

Environ. Sci. Technol., Just Accepted Manuscript • DOI: 10.1021/acs.est.8b04070 • Publication Date (Web): 19 Oct 2018

Downloaded from http://pubs.acs.org on October 23, 2018

\section{Just Accepted}

"Just Accepted" manuscripts have been peer-reviewed and accepted for publication. They are posted online prior to technical editing, formatting for publication and author proofing. The American Chemical Society provides "Just Accepted" as a service to the research community to expedite the dissemination of scientific material as soon as possible after acceptance. "Just Accepted" manuscripts appear in full in PDF format accompanied by an HTML abstract. "Just Accepted" manuscripts have been fully peer reviewed, but should not be considered the official version of record. They are citable by the Digital Object Identifier (DOI®). "Just Accepted" is an optional service offered to authors. Therefore, the "Just Accepted" Web site may not include all articles that will be published in the journal. After a manuscript is technically edited and formatted, it will be removed from the "Just Accepted" Web site and published as an ASAP article. Note that technical editing may introduce minor changes to the manuscript text and/or graphics which could affect content, and all legal disclaimers and ethical guidelines that apply to the journal pertain. ACS cannot be held responsible for errors or consequences arising from the use of information contained in these "Just Accepted" manuscripts. 


\section{Investigating fluorescent organic matter composition as a key predictor for}

\section{2 arsenic mobility in groundwater aquifers}

3 Anna-Ricarda Schittich ${ }^{\text {a,* }}$, Urban J. Wünsch ${ }^{\text {b,c }}$, Harshad V. Kulkarni ${ }^{\text {d, }}$, Maria Battistel a, Henrik

4 Bregnhøj ${ }^{\mathrm{e}}$, Colin A. Stedmon ${ }^{\mathrm{c}}$, Ursula S. McKnight ${ }^{\mathrm{a}}$

${ }^{a}$ Department of Environmental Engineering, Technical University of Denmark, Bygningstorvet,

Building 115, 2800 Kgs. Lyngby, Denmark

${ }^{b}$ Water Environment Technology, Chalmers University of Technology, Architecture and Civil

Engineering, Sven Hultins Gata 6, 41296 Gothenburg, Sweden

${ }^{c}$ National Institute of Aquatic Resources, Technical University of Denmark, Kemitorvet, Building 202,

${ }^{d}$ Department of Geology, Kansas State University, Manhattan, KS, USA, 66502

${ }^{e}$ School of Global Health, University of Copenhagen, 1353 Copenhagen K, Denmark

* To whom the correspondence should be addressed: Email: annsc@env.dtu.dk

The authors declare no conflict of interest. 


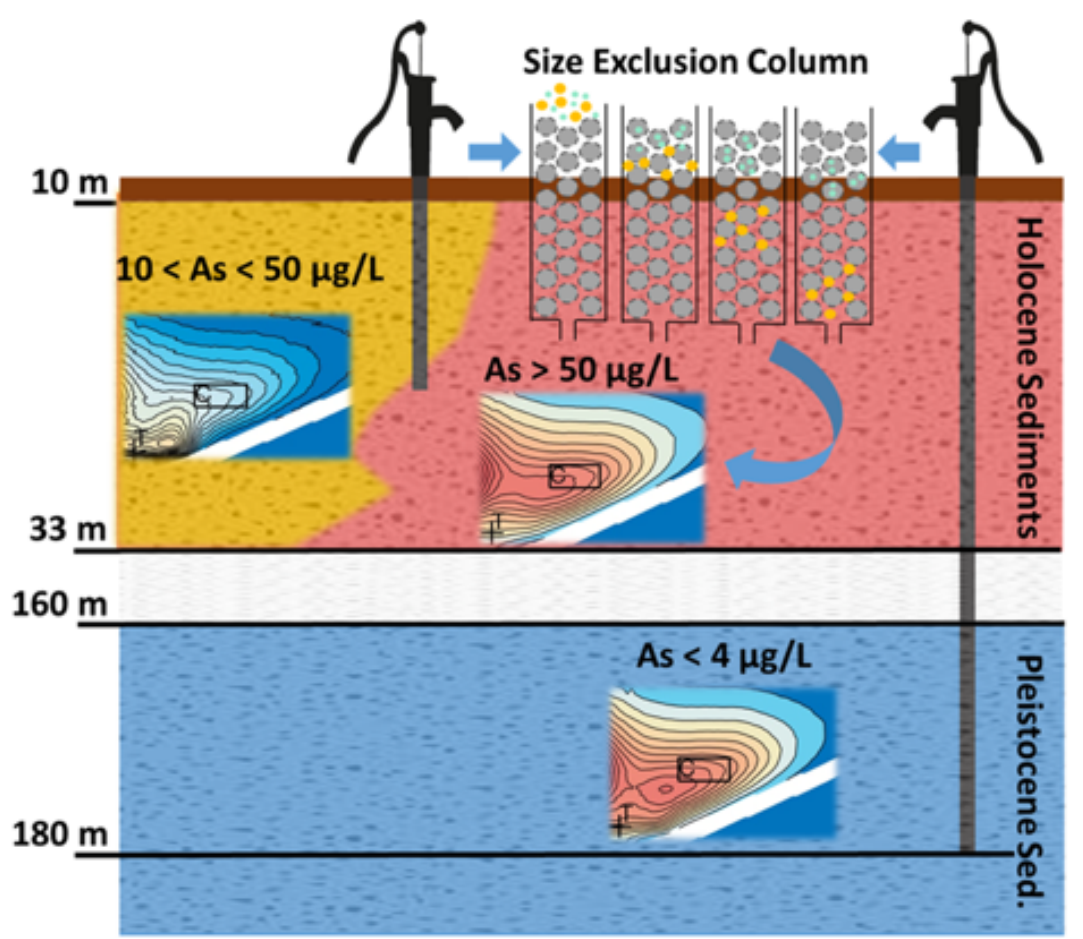




\section{Abstract}

25 Dissolved organic matter (DOM) is linked to the heterogeneous distribution of elevated arsenic (As) in groundwater used for drinking and irrigation purposes, but the relationship between DOM characteristics and arsenic mobility has yet to be fully understood. Here, DOM from groundwater sampled in the Bengal Basin region was characterized using both conventional bulk emission-excitation (EEM) spectroscopy and high-performance size exclusion chromatography coupled to spectroscopy (HPSEC-EEM). Notably, application of the novel HPSEC-EEM approach permitted the total fluorescence of individual samples to be independently resolved into its underlying components. This allowed the external validation of the bulk-sample fluorescence decomposition and offered insight into the molecular size distribution of fluorescent DOM. Molecular size distributions were similar for the UVA fluorescent $\left(\mathrm{C}_{310}, \mathrm{C}_{340}\right)$ as well as the three visible fluorescent $\left(\mathrm{C}_{390}, \mathrm{C}_{440} \mathrm{C}_{500}\right)$ components. There was a greater visible fluorescence in shallow aquifer samples $(10-33 \mathrm{~m})$ with high As ( $\mathrm{SH}$, up to $418 \mu \mathrm{g} / \mathrm{L}$ ) than in samples from the same depth with lower As (up to $40 \mu \mathrm{g} / \mathrm{L}$ ). This indicated a link between DOM quality and As mobility within the shallow aquifer. The deep aquifer samples (170-200 m) revealed DOM characteristics similar to SH samples but had low As concentrations $(<4 \mu \mathrm{g} / \mathrm{L})$, signifying that the deep aquifer is potentially vulnerable to As contamination. These findings pave the way for a more comprehensive assessment of the susceptibility of drinking water aquifers, thereby supporting the management of groundwater resources. 


\section{Introduction}

Many groundwater aquifers serving as the primary drinking water resource in Asia are severely polluted with arsenic (As). Some of the most problematic areas are located in the geological formations of the Bengal Basin, which cover large parts of West Bengal (India) and Bangladesh. Total As concentrations considerably exceeding the Indian drinking water standard of $10 \mu \mathrm{g} / \mathrm{L}(50 \mu \mathrm{g} / \mathrm{L}$ in the absence of alternative water sources) are a widespread concern for public health. ${ }^{1-8}$ The degradation of labile dissolved organic matter (DOM) is considered to be the main driver for As mobilization in this area. ${ }^{2,3,9,10}$ Specifically, the microbial utilization of DOM causes reducing conditions in the aquifer which subsequently leads to the dissolution of As-bearing oxide minerals, as well as the release of As sorbed onto iron hydr(oxides). ${ }^{2,3,7,11-13}$ While sedimentary DOM from peat layers, ${ }^{9,14-16}$ as well as surfacederived organic carbon, ${ }^{17-19}$ have been suggested, the source of labile DOM is still a matter of much debate. ${ }^{20,21}$ Beyond labile DOM, recent studies also highlight the potential influence of humic and fulvic acids (refractory organic polymers) in As mobilization through electron shuttling, ${ }^{22-25}$ or competition for sorption, ${ }^{26}$ and complexation processes. ${ }^{27,28}$ Since the chemical composition of DOM defines its reactivity in the environment, ${ }^{29,30}$ the ability to track the different chemical fractions of DOM is essential to better understand its role on arsenic mobilization in groundwater.

Over the last decades, absorbance and fluorescence spectroscopy have increasingly been applied to characterize groundwater DOM in relation to As contamination. ${ }^{8,24,31,32}$ The fluorescing fraction of DOM, fluorescent dissolved organic matter (FDOM), can be characterized by recording fluorescence emission as a function of excitation wavelength. The resulting emission-excitation matrices (EEMs) can further be mathematically decomposed into their underlying individual fluorescent phenomena by methods such as parallel factor analysis (PARAFAC). ${ }^{33,34}$ Recent studies used fluorescence ratios, such as freshness and the humification index, as well as PARAFAC modelling to analyze shallow groundwater samples from West Bengal and have observed a link between humic-like DOM and high As concentrations. ${ }^{8,32,35}$ However, a common caveat in PARAFAC modeling is that datasets must contain sufficient variability in fluorescent properties; therefore large datasets ( $>100$ samples) are 
preferable. ${ }^{36}$ This represents a barrier preventing the widespread implementation of this method in practice, i.e. in field studies, as it is often not possible to collect such large datasets due both to financial and practical constraints.

Recently, a new analytical framework has been developed that produces $>1000$ EEMs originating from a single water sample, which allows the mathematical decomposition of fluorescence in single samples. ${ }^{37}$ This is achieved through the online-coupling of high-performance size exclusive chromatography (HPSEC) with fluorescence EEM spectroscopy. Application of the HPSEC approach also links fluorescence phenomena to their molecular size distributions, an important indicator that may reveal information about the susceptibility to degradation of different DOM compounds. ${ }^{38,39}$ HPSEC coupled to spectroscopic measurements additionally offers the possibility to investigate interactions between DOM and other elements such as As in contaminated aquifers. ${ }^{28}$

The overall goal of this study was to characterize groundwater DOM taken from a village in West Bengal by applying fluorescence spectroscopy and to investigate links to As mobilization. We aimed to characterize FDOM of bulk samples and link fluorescence to molecular size by applying HPSEC-EEMPARAFAC for groundwater samples. Based on this information, we aimed to group samples taken from different aquifers with respect to the hydrochemistry. The final goal was to establish links between FDOM characteristics and the abundance of As, i.e. to investigate whether distinct fluorescent characteristics can be observed for samples from specific aquifers with differing arsenic content (below and above the local As drinking water standard of $50 \mu \mathrm{g} / \mathrm{L}$ ). This could provide information about the mechanisms driving As distributions and ultimately support the management of groundwater resources.

\section{Material and Methods}

\subsection{Study site}

The field study site is located in the village of Gazna ( $\left.22^{\circ} 54^{\prime} 15.9^{\prime \prime} \mathrm{N}, 88^{\circ} 48^{\prime} 28.7^{\prime \prime} \mathrm{E}\right)$, in the western part of the Bengal Basin. The geology of the site shows relatively shallow, organic rich, Holocene 
sediments $(<11$ thousand years before present $[\mathrm{bp}])$ separated from deeper Pleistocene sand and gravel deposits (2600-12 thousand years bp) by a low permeable clay layer, typical of the Bengal Basin. ${ }^{40-44}$ The vertical extension of Holocene sediments varies locally, and while it can reach depth levels up to 100 meters below ground surface (mbgs), ${ }^{45,46}$ it may also be limited to much shallower depths. ${ }^{47,48} \mathrm{~A}$ study located in the Jamuna sub-basin (roughly $30 \mathrm{~km}$ west of this study site) described the interface between Holocene and Pleistocene sediments at approximately 30 mbgs. ${ }^{49}$ The Holocene aquifer is henceforth referred to as the shallow aquifer and is locally used for domestic and irrigation purposes. Several authors suggest this aquifer system displays a very complex, heterogeneous structure, comprised of a series of sub-aquifers separated by thin clay layers that may extend for up to a few kilometers horizontally. ${ }^{50-52}$ Precise geochemical and hydrologic information about this aquifer at the study site is very limited, even though the lithology in neighboring areas is known. ${ }^{49}$ Shallow aquifer samples have been documented throughout this region by As concentrations greatly exceeding the Indian drinking water standard, reaching $1000 \mu \mathrm{g} / \mathrm{L},{ }^{5}$ where the sediment is most commonly described as grey-colored and anoxic. ${ }^{46}$ Holocene sediment cores from a neighbouring district (ca. $75 \mathrm{~km}$ south-west of our study site) revealed As concentrations up to $12.6 \mathrm{mg} / \mathrm{kg}$ sediment, ${ }^{53}$ where the Holocene sediments are overlain by a silty clay layer of overbank deposits forming the surface aquitard. ${ }^{54}$

The primary aquifer, henceforth referred to as the deep aquifer, flows in the Pleistocene sediments and is located ca. $170 \mathrm{mbgs}$ at this study site. In contrast to the high lateral variability found in the shallow aquifers, groundwater extracted from depths $>150$ mbgs rarely contain As concentrations above 50 $\mu \mathrm{g} / \mathrm{L} .{ }^{44,55}$ Low dissolved As concentrations in deep aquifers with reducing conditions were previously reported due either to a low As source in the sediment, ${ }^{46,56,57}$ or the presence of pyrite acting as an As sink, ${ }^{58,59}$ while oxidized Pleistocene sediments showed a large capacity for adsorbing dissolved As consequently leading to low As concentrations in the water. ${ }^{60}$

\subsection{Investigation strategy and sampling}

The local Indian NGO (non-governmental organization) Kishalaya Tarun Tirtha (KTT) and the Danish NGO Ulandsforeningen for Bæredygtig Udvikling (UBU) have worked together on awareness and 
supported a number of measurement campaigns in the village of Gazna since 2004 (Supporting Information (SI), Fig. S1). For this study, additional fieldwork was carried out in April 2017 in cooperation with the two NGOs. To obtain an overview of the level of As contamination in the surrounding study area and to guide the additional collection of samples, existing groundwater borehole (i.e. tube well) data was used to create preliminary maps in ArcGIS (v.10.3) applying inverse distance weighting (IDW) interpolation (for more details, see SI Methods, SI Figs. S1-S2).

For the laboratory analysis, a total of 50 samples were collected. Forty were sampled from the shallow aquifer system containing both low $(<50 \mu \mathrm{g} / \mathrm{L})$ and high $(>50 \mu \mathrm{g} / \mathrm{L})$ total dissolved As concentrations (SI Fig. S2). For the deep aquifer, no initial data was available and thus groundwater was collected from nine deep tube wells distributed throughout the different parts of the village (SI Fig. S2) and one deep tube well of a school, just outside the village borders. Note that Gazna is one of the villages where the exceptional standard of $50 \mu \mathrm{g} / \mathrm{L}$ applies for arsenic. All samples were collected in April 2017 during a very dry period, just before the start of the rainy season. All samples for the chemical analysis (see section 2.3) were immediately filtered through a $0.45 \mu \mathrm{m}$ nylon filter for particulates removal and acidified with nitric acid $\left(\mathrm{HNO}_{3}\right)$ to $\mathrm{pH}<2$. Samples for absorbance and fluorescence spectroscopy (section 2.4) were not acidified to avoid fluorescence quenching, ${ }^{61}$ and filtered through a $0.2 \mu \mathrm{m}$ nylon filter. ${ }^{62}$ After collection, the samples were stored at $4-8{ }^{\circ} \mathrm{C}$ for a maximum of 2-7 days and refrigerated during transportation to the Technical University of Denmark (DTU) for analysis. Upon arrival, samples were stored at $4{ }^{\circ} \mathrm{C}$ in the dark.

\subsection{Chemical analysis}

139 Concentrations of As, phosphorus (P), iron (Fe) and manganese (Mn), as well as dissolved organic 140 carbon (DOC) were measured for all sampling sites. Dissolved As and P were measured using 141 inductively coupled plasma mass spectrometry (ICP-MS) ca. 15 days after collection using an Agilent

142 Technologies 7700 Series ICP-MS. Detection limits were $1.0 \mu \mathrm{g} / \mathrm{L}$ and $13.0 \mu \mathrm{g} / \mathrm{L}$ for As and P, 143 respectively. Fe and Mn were measured with inductively coupled plasma optical emission spectrometry 
144 (ICP-OES) within five weeks of collection. The measurements were carried out with a Perkin Elmer 145 Avio $^{\mathrm{TM}} 200$ duel view ICP-OES. Detection limits were $0.3 \mu \mathrm{g} / \mathrm{L}$ and $0.1 \mu \mathrm{g} / \mathrm{L}$ for $\mathrm{Fe}$ and $\mathrm{Mn}$, 146 respectively. DOC was measured within two weeks of collection using high-temperature combustion 147 (TOC-VWP, Shimadzu) in the form of non-volatile organic carbon (NVOC) with a detection limit of $0.07 \mathrm{mg} / \mathrm{L}$.

\subsection{Spectroscopic data}

150 Absorbance and fluorescence spectroscopy was carried out with two approaches described in detail 151 below.

\subsubsection{Bulk EEM spectroscopy}

153

Spectroscopic data for all 50 bulk samples was obtained within three weeks after sample collection using a Horiba Aqualog fluorometer with a quartz cuvette of $0.01 \mathrm{~m}$ path length. Absorbance data was collected between 240-600 nm (increment $3 \mathrm{~nm}$ ). Specific UV absorbance at $254 \mathrm{~nm}\left(\mathrm{SUVA}_{254}\right)$ was used to obtain information about the aromatic carbon content of the samples and calculated as the ratio of absorbance intensity at $254 \mathrm{~nm}$, divided by the product of path length and DOC concentration. ${ }^{63}$ Fluorescence emission was recorded at excitation wavelengths between $240-600 \mathrm{~nm}$ at $3 \mathrm{~nm}$ increments and then measured at emission wavelengths between $240-600 \mathrm{~nm}$ at increments of $\sim 3.28 \mathrm{~nm}$ (instrument default). The integration time varied between $1 \mathrm{~s}$ and $3 \mathrm{~s}$, depending on the carbon concentration of the samples.

To investigate a possible interference from the high As concentrations (i.e. quenching effects) on the fluorescence measurements, two batch experiments were carried out as described in the SI (SI Methods).

\subsubsection{HPSEC-EEM spectroscopy}

Seven samples were additionally analyzed with HPSEC coupled to absorbance and fluorescence detection within seven months of sample collection, including samples from the shallow aquifer with low dissolved As $(<50 \mu \mathrm{g} / \mathrm{L}, \mathrm{SL})$; samples from the shallow aquifer with high dissolved As $(>50 \mu \mathrm{g} / \mathrm{L}$, 
$168 \mathrm{SH}$ ) and samples from the deep aquifer (D). HPSEC was performed using a Shimadzu Nexera X2UFLC 169 system equipped with a TSKgel SuperAWM-H column and two sequential detectors, following the 170 methodology described elsewhere. ${ }^{37}$ Absorbance was measured between $240-700 \mathrm{~nm}$ at $1 \mathrm{~nm}$ intervals 171 using a Shimadzu SPD-M30 detector. Fluorescence emission was detected between 300-600 nm with 172 an interval of $5 \mathrm{~nm}$ across an excitation of 240-450 nm (increment $5 \mathrm{~nm}$ between $240-360 \mathrm{~nm}$, then 10 $173 \mathrm{~nm}$ between 360-450 nm) using a Shimadzu RF-20Axs detector (for more details, see SI Methods and 174 Wünsch et al. $\left.^{37}\right)$.

\subsubsection{Data processing}

For both datasets (obtained from bulk EEM and HPSEC-EEM measurements), EEMs were processed using the drEEM toolbox (v.0.3.0) in MATLAB 9.3. ${ }^{64}$ For bulk EEMs, inner filter effects were corrected with the absorbance-based approach, which was appropriate for the absorbance intensities of the dataset. ${ }^{65}$ After the subtraction of a blank EEM, first and $2^{\text {nd }}$ order physical scatter was removed and interpolated only for the first order Rayleigh scatter. HPSEC-EEMs were corrected following the protocol described elsewhere. ${ }^{37}$ The fluorescence intensity in all EEMs was normalized by division of fluorescence counts with the Raman peak area at $350 \mathrm{~nm}$.

For both datasets, the humification index (HIX) was calculated from the emission intensities at the peak area $435-480 \mathrm{~nm}$ divided by the sum of the peak areas 300-345 nm and 435-480 $\mathrm{nm}$ at an excitation wavelength of $254 \mathrm{~nm} .{ }^{66}$ Fluorescence index and freshness index were calculated as described elsewhere. ${ }^{67,68} \mathrm{UV}$ fluorescence at peak T, which represents the signal at $275 \mathrm{~nm} / 340 \mathrm{~nm}(\mathrm{Ex} / \mathrm{Em})$, was extracted from the datasets. ${ }^{69,70}$ Peak C was extracted at $320-360 \mathrm{~nm} / 420-460 \mathrm{~nm}(\mathrm{Ex} / \mathrm{Em})$ as a measure

188 for the visible $(\mathrm{Ex}>300 \mathrm{~nm})$ fluorescence emission region. ${ }^{69,70}$

\subsection{Chemometric analyses}

PARAFAC was used to identify the fluorescence components that comprise bulk and HPSEC EEMs. 
HPSEC-EEMs. Models were constrained to non-negativity; a relative change of $10^{-7}$ from one iteration to the next was used as a convergence criterion. For the classical PARAFAC model, a dataset of 48 samples was used after removing two outliers. With only 48 samples, we were able to split-validate a four-component model. The spectral loadings of models with up to six components appeared reasonable, but could not be validated.

For HPSEC-EEMs, one PARAFAC model was fit to a dataset consisting of a total of 1330 EEMs. This dataset was comprised of 190 equally spaced EEMs from the seven samples (190 x 7) measured by HPSEC-EEM between elution volumes of 3.1 and $5 \mathrm{~mL}$. This is equal to one EEM every $10 \mu \mathrm{L}$ or $2 \mathrm{~s}$ in the separation. The best fit was obtained with an overall model with five components, which was subsequently fit to the full datasets of all seven samples. To evaluate the appropriateness of this approach, sum-of-squared-errors for the global model in all seven samples were subsequently investigated. Fitting the global solution to individual samples resulted in less than $0.05 \%$ unexplained variance in all cases (SI Fig. S3). Furthermore, we used the spectral comparison between the unvalidated bulk FDOM five-component model fit to the 48 bulk EEMs and the five-component model fit to the 1330 HPSEC EEMs to provide a means to externally validate both models. The Tucker congruence coefficient (TCC) was used to assess spectral congruence between components. ${ }^{71,72}$

\subsection{Statistical data treatment}

Principal Component Analysis (PCA) was used to group and characterize the groundwater samples according to their geochemical (As, Fe, Mn, P) and spectral composition (SUVA 254, PARAFAC components). Ordination techniques, such as PCA, can be combined with cluster analyses (here, hierarchical cluster analysis (HCA) was used, applying a SIMilarity PROFile analysis (SIMPROF) $\mathrm{p}<0.05)$ to obtain a better interpretation of the ordination diagrams and help identify wells belonging to the same clusters. ${ }^{73}$ Data were $4^{\text {th }}$ root transformed across the sample dimension to equalize sample leverage, and centered and scaled across variables to equalize variable leverage (zero mean, unit variance) before the PCA and cluster analyses were performed. 


\section{Results and Discussion}

\subsection{Fluorescence composition and molecular size distributions of DOM}

The optical properties of bulk groundwater samples were typical for DOM samples from this region. Fluorescence intensities at peak $\mathrm{T}$ and peak $\mathrm{C}$ varied from 0.06-0.42 R.U. and 0.09-1.32 R.U., respectively. HIX and $\mathrm{SUVA}_{254}$ showed values from $0.56-0.89$ and $0.82-6.84$, respectively (SI Tables S1-S2). The fluorescence index was relatively constant throughout all samples (1.64-1.89) while the freshness index varied between $0.75-1.26$, where smaller values are representative for more decomposed DOM. ${ }^{74}$

PARAFAC conducted on the 50 bulk samples revealed that four to six components described 99.83$99.92 \%$ of the variability. The successfully validated four-component PARAFAC model featured one UVA fluorescent (protein-like) component, as well as three visible wavelength (humic-like) components (Ex. > $300 \mathrm{~nm}$ ) (SI Fig. S4a). Despite spectral loadings that resembled pure fluorophores, a fivecomponent model could not be validated (SI Fig. S4b). Therefore, HPSEC-EEM-PARAFAC was used to externally cross-validate the five-component bulk PARAFAC model based on the seven-sample subset (Fig. 1a-e). The results show that the fluorescence signal can be decomposed into similar components (Fig. 1a-e), named $\mathrm{C}_{310}, \mathrm{C}_{340}, \mathrm{C}_{390}, \mathrm{C}_{440}$ and $\mathrm{C}_{500}$ according to their fluorescence emission maxima with respective excitation maxima at $265 \mathrm{~nm}, 280 \mathrm{~nm}, 305 \mathrm{~nm}, 350 \mathrm{~nm}$ and $390 \mathrm{~nm}$. However, the external cross-validation revealed some degree of dissimilarity for $\mathrm{C}_{310}$ and $\mathrm{C}_{340}$, (Fig. 1a-b). Considering that the comparison of models fit to data obtained on separate instruments under different conditions is challenging, ${ }^{75}$ the failure to obtain highly similar fluorescence components at low wavelengths most likely reflects the varying degree of influence of scatter peaks at low wavelengths between detectors. For $\mathrm{C}_{390}, \mathrm{C}_{440}$ and $\mathrm{C}_{500}$ (Fig. 1c-e), conventional validation thresholds were met for congruence between components $(\mathrm{TCC}>0.95) .{ }^{76}$ Thus, the results offer compelling evidence that bulk EEM fluorescence can be described by means of PARAFAC models obtained on a single sample. The external cross-validation approach offers a unique opportunity to validate otherwise unstable 
242 PARAFAC models from a small dataset. The UVA fluorescence components $\mathrm{C}_{310}$ and $\mathrm{C}_{340}$ have 243 previously been defined as protein-like components, ${ }^{75,77,78}$ and show a mean contribution of $11 \%$ and $19 \%$ to the total fluorescence, respectively. The visible fluorescence components $\mathrm{C}_{390}, \mathrm{C}_{440}$ and $\mathrm{C}_{500}$ show mean contributions of $26 \%, 34 \%$ and $10 \%$, respectively and are often defined as humic-like. ${ }^{8,78-}$ ${ }^{80} \mathrm{C}_{390}$ and $\mathrm{C}_{440}$ match with two components $(\mathrm{C} 2, \mathrm{C} 1)$ found in shallow groundwater at a nearby site (ca. $75 \mathrm{~km}$ distance), ${ }^{8}$ reaching similarity scores of 0.99 and 0.97 , respectively.

The utilization of HPSEC-EEM analysis permitted the in-depth analysis of apparent molecular size distributions of FDOM for the seven-sample subset (see definition in section 2.4.2). In general, HPSEC yields apparent molecular size distributions of DOM after calibration with a standard. However, apparent size distributions may be influenced by the occurrence of secondary interactions with the column, ${ }^{81}$ i.e. adsorption of hydrophobic compounds resulting in artificially low molecular weight. ${ }^{82}$ Distributions are therefore shown as a function of elution volume (Fig. 1f-j), which is generally inversely correlated to molecular size. Fractions eluting at a volume larger than $4 \mathrm{~mL}$ are outside the calibration range (i.e. appear smaller than $20 \mathrm{Da}$ ), but the separation still offers insight into DOM composition unrelated to molecular size.

UVA fluorescence $\left(\mathrm{C}_{310}, \mathrm{C}_{340}\right)$ revealed two elution peaks in the larger molecular size fraction at ca. 3.3 $\mathrm{mL}$ and $3.5 \mathrm{~mL}(\sim 2 \mathrm{kDa}$ and $\sim 0.6 \mathrm{kDa}$, respectively) and a third elution peak in the smaller molecular size fraction at ca. $4.0 \mathrm{~mL}(\sim 20 \mathrm{Da})$, where the contribution of secondary interactions probably led to the artificially large elution volume (Fig. 1f-g). For the SL samples, fluorescence of component $\mathrm{C}_{310}$ is clearly associated with smaller molecular size fractions (the third peak is dominant in SL samples) while a shift towards the larger molecular size fraction tends to occur for SH and D samples (Fig. 1f). A similar pattern was observed for $\mathrm{C}_{340}$, which is mainly associated with the larger molecular size fraction for $\mathrm{SH}$ and D samples, while for SL samples, the third peak also contributes considerably to the fluorescence signal (Fig. 1g). Visible fluorescence $\left(\mathrm{C}_{390}, \mathrm{C}_{440}, \mathrm{C}_{500}\right)$ is consistently associated with the large size fraction (two peaks at ca. $3.3 \mathrm{~mL}$ and $3.5 \mathrm{~mL}$ ) independent of the sample group (Fig. 1h-j), but is considerably higher for the SH and D samples compared to SL samples. Overall, the HPSEC-EEM- 
PARAFAC analysis indicated similar fluorescence distributions over the chromatograms between the two protein-like, as well as the three humic-like components. Small shifts in molecular size distribution and different fluorescence intensities for different sample groups point towards a qualitative difference in DOM among the samples.

(a) $0.98 / 0.69$

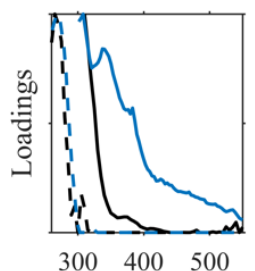

(b) $0.83 / 0.76$
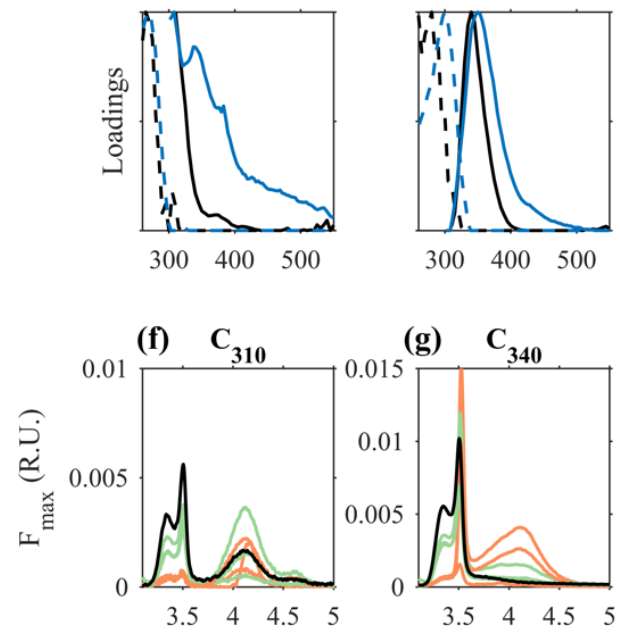

272

273

274

275

276

277

\subsection{Hydro-chemical classification of aquifers}

(c) $0.99 / 0.97$

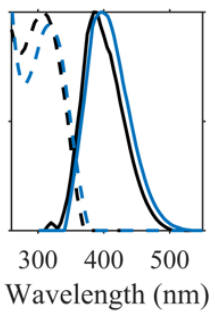

(h) $\mathrm{C}_{390}$

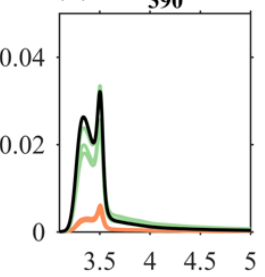

Elution volume $(\mathrm{mL})$ (d) $0.99 / 0.98$

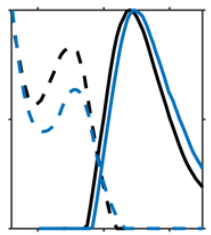

$300 \quad 400 \quad 500$

(i) $\mathrm{C}_{440}$

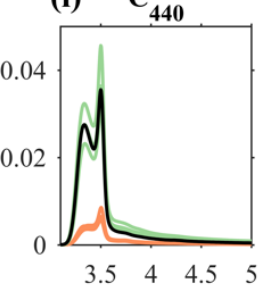

(e) $0.97 / 0.96$

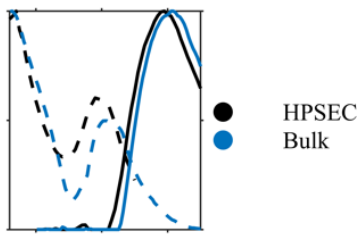

$300 \quad 400 \quad 500$

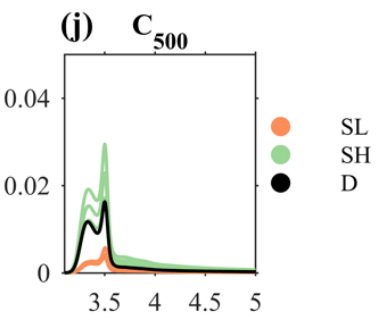

Figure 1: Cross-validation (a-e) of the five-component bulk PARAFAC model (blue) by using an independent HPSEC-EEM-

PARAFAC model (black) and TCC values indicating similarity scores between the two models for the excitation (first number, dashed line) and emission (second number, solid line) curves. For each PARAFAC component (a-e), the distribution of the maximum fluorescence intensity $\left(F_{\max }\right)$ over the chromatogram is shown for all 7 samples analyzed by HPSEC (f-j).

The characterization of the shallow and deep aquifers was based on dissolved As, Fe, Mn, P and DOC concentrations, as well as absorbance and fluorescence characteristics. The reliability of the preliminary As distribution maps (section 2.2) was tested during the fieldwork by checking the predicted concentrations for several areas. As a result, the maps served as a satisfying tool to distinguish contamination levels (SI Fig. S2), which was especially helpful regarding very limited information and equipment at the study site. The shallow aquifer showed very heterogeneous, and much higher, dissolved As concentrations than the deep aquifer. Dissolved As concentrations ranged from 1-40 $\mu \mathrm{g} / \mathrm{L}$ for SL samples, from 57-418 $\mu \mathrm{g} / \mathrm{L}$ for SH samples, and from $<1-4 \mu \mathrm{g} / \mathrm{L}$ for D samples (SI Tables S1-S2). DOC 
concentrations did not differ much between the three groups, for all samples DOC varied from 0.64 $3.39 \mathrm{mg} / \mathrm{L}$ (SI Tables S1-S2), and were lower than reported in related studies. ${ }^{8,23}$ However, shallow aquifer samples (SL; SH) showed considerably higher dissolved Fe, Mn and P concentrations compared to D samples (SI Tables S1-S2).

The PCA based on As, Fe, Mn and P could explain $90.58 \%$ of the variance between the samples with two principal components $(\mathrm{PC} 1+\mathrm{PC} 2)$ and the HCA split the samples into four significantly different clusters (SIMPROF $\mathrm{p}<0.05$, Fig. 2a). With one exception (D sample of $4 \mu \mathrm{g} \mathrm{AsL}{ }^{-1}$ clustering with SL sample of $1 \mu \mathrm{g} \mathrm{AsL}^{-1}$ ), all D samples clustered in one group, indicative of a hydrologically distinct (deep) aquifer. A low arsenic concentration may reflect the lack of As-containing iron/manganese minerals in the deep aquifer sediments, which also aligns with the low dissolved Fe and $\mathrm{Mn}$ concentrations observed in the D-samples. The shallow aquifer samples split into two clusters where SH samples tended to gather in one cluster. However, a clear separation between SL and SH samples is not given (Fig. 2a), indicating that, although the shallow aquifer has been (arbitrarily) divided into different sub-aquifers, the interaction between them is widespread and probably enhanced by the local use of the tube-wells.

Generally, high concentrations of dissolved $\mathrm{Fe}$ and $\mathrm{Mn}$ in the shallow aquifer are consistent with other studies in the Bengal Basin and are indicative for the reductive dissolution processes of $\mathrm{Fe}$ and $\mathrm{Mn}$ minerals, possibly leading to arsenic mobilization. ${ }^{11,83}$ However, this does not explain the very heterogeneous distribution of As within the shallow aquifer. As mobilization due to competition with phosphate $\left(\mathrm{PO}_{4}{ }^{3-}\right),{ }^{84}$ or the enhancement of $\mathrm{OM}$ degradation through phosphate, ${ }^{7}$ might be relevant processes to analyze further. Moreover, groundwater age linked to hydrogeological conditions in the flow system may also play a role in determining the spatial As distribution, for example through flushing of As. ${ }^{85}$ Hydrogeological conditions, likely influenced by pumping activities, can additionally cause the cycling of labile organic carbon, ${ }^{44,86}$ possibly leading to a spatial variability in DOM source and quality along with varying redox potential. ${ }^{32}$ For example, Harvey et al., ${ }^{44}$ found that the mobilization of As may be driven by young carbon transported to depth through irrigation pumping. 
312 Even though DOC concentrations were similar for all samples in this study, the degree of colored

313 material differed between samples. A PCA based on As, $\mathrm{C}_{310}, \mathrm{C}_{340}, \mathrm{C}_{390}, \mathrm{C}_{440}, \mathrm{C}_{500}$ and SUVA254 (Fig.

$3142 \mathrm{~b}$ ) explained $81.38 \%$ of the variance with PC1 and PC2 and indicated a positive correlation between 315 most of the $\mathrm{SH}$ samples and the visible fluorescent components $\left(\mathrm{C}_{390}, \mathrm{C}_{440}, \mathrm{C}_{500}\right)$ as well as $\mathrm{SUVA}_{254}$, 316 indicating increasing aromaticity. SL samples were mostly located diagonally opposite to $\mathrm{C}_{390}, \mathrm{C}_{440}, \mathrm{C}_{500}$ and $\mathrm{SUVA}_{254}$ (negative correlation). This points towards a qualitative difference in DOM between the samples of the shallow aquifer possibly linked to different DOC sources. The two UVA components $\left(\mathrm{C}_{310}, \mathrm{C}_{340}\right)$ were negatively correlated to As. SH and D samples mainly differed in PC2 (y-axis), driven by the difference in As concentration (Fig. 2b).

a)

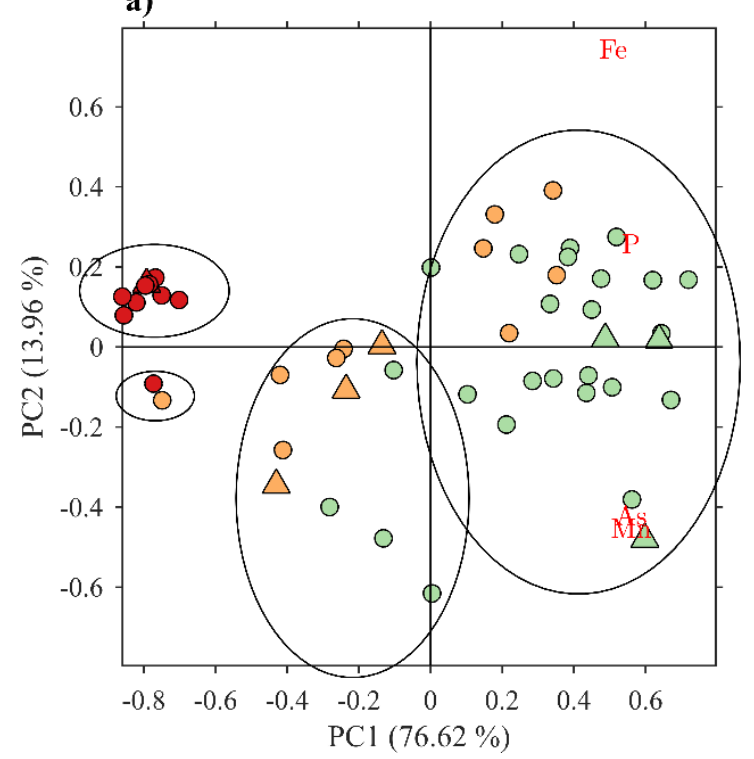

b)

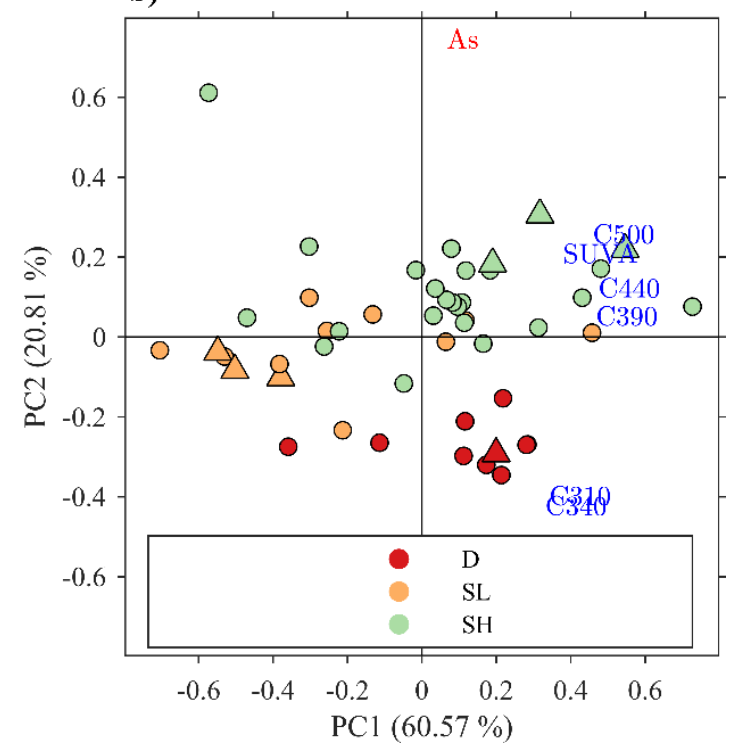

Figure 2: (a) Principal component analysis (PCA) based on As, Fe, Mn and P, and (b) PCA based on As, $\mathrm{SUVA}_{254}$ and the five PARAFAC components. Triangles indicate the seven samples additionally analyzed with HPSEC. Black circles indicate significantly different cluster groups based on HCA.

\subsection{Links between DOM composition and As mobility}

326 General fluorescence parameters (peak T, peak C, HIX) and their distribution over the chromatogram 327 were used to investigate whether distinct fluorescent characteristics can be observed for the three different sample groups (SL, SH and D). The general fluorescence characteristics of one representative 
sample for each group are shown in Fig. 3 (characteristics for all samples are given in SI Figs. S5-S9).

DOM fluorescence intensity was lower for SL samples (0-0.2 R.U.) than for SH (0-1.2 R.U.) and D (00.8 R.U.) samples (Fig. 3a-c, z-axis), whereby the high fluorescence intensities in the SH and D samples align with a high fluorescence in the $\mathrm{C}$ peak region. The distribution of peak $\mathrm{T}$ (UV fluorescence) and peak C (visible fluorescence) over the chromatogram (Fig. 3d-e) is comparable with the chromatographic distribution of the UV and visible fluorescence PARAFAC-components, respectively (Fig. 1f-j) (for detailed chromatographic peak positions of peak T and peak C, see SI Table S3).

HIX, which is roughly comparable to the ratio of peak $\mathrm{T}$ to peak $\mathrm{C}$, displays clear differences along the chromatogram and a consistent pattern can be seen across all three sample groups (Fig. 3d-f). Our results suggest that, along the chromatogram (changing molecular size), an increase in HIX is related to a decrease in protein-like fluorescence. The late minimum $(4.0 \mathrm{~mL})$ in HIX in the chromatograms results from a relative increase in the T peak fluorescence (Fig. 3d-e) even though fluorescence is low (Fig. 3f). The greatest variability in the chromatograms across the three sample groups was due to the increase of peak C for SH and D samples (Fig. 3d-f), whereas peak T was relatively comparable. This drove the slight increase in the measured HIX in the bulk samples (SI Tables S1-S2) and is linked to the process of humification where labile substrate is transformed into material with visible wavelength fluorescence (peak C). Peak T and C are often referred to as protein-like and humic-like fluorescence, respectively. 70

347 From this perspective, our results for the shallow aquifer fit with the findings of Kulkarni et al., ${ }^{8,35}$ who characterized bulk sample DOM from shallow groundwater with high arsenic concentrations in a nearby study area as more humic-like, compared to samples with low arsenic concentrations. To test if our

350 findings reflected other effects such as fluorescence quenching, rather than differences in DOM 351 characteristics for SL and SH samples, two batch experiments were carried out (SI Methods) where a 352 loss of fluorescence signal, as would be expected from quenching effects, could not be observed (SI Fig. 353 S10-S11). Quenching effects caused by high iron concentrations might also play a role, ${ }^{87}$ however, they appear to not be driving the variability observed in our samples. Sample SH26 has similar fluorescence 
characteristics to sample D4 (compare Fig. 3e and Fig. 3f), despite an order of magnitude difference in iron concentrations $(4.20 \mathrm{mg} / \mathrm{L}$ and $0.67 \mathrm{mg} / \mathrm{L}$, respectively). Similarly, the $\mathrm{SH}$ samples have relatively higher Fe concentrations and fluorescence compared SL samples. If quenching was important in driving the trends seen one would expect an inverse correlation. The different EEM characteristics therefore likely arise from qualitatively different DOM, which promotes or prevents As mobility in groundwater. Remarkably, the deep aquifer (low in As) shows DOM characteristics similar to SH, not SL samples, having a high fluorescence in the humic-peak region (compare Fig. 3b-c, 3e-f). The similarity between SH and D samples is also reflected in the PCA in Fig. 2b, where SH and D samples show similar characteristics along PC1 (x-axis). The combination of low As and dominant humic peak may indicate an aquifer with reducing conditions where, however, the source of As is missing in the sediment. Even though low concentrations of sedimentary As $(1.8 \mathrm{mg} / \mathrm{kg}$, average crustal abundance) are sufficient to mobilize As with dissolved concentrations greater than $10 \mu \mathrm{g} / \mathrm{L},{ }^{88}$ it has been documented that sorbed As has been removed from the Pleistocene sediments in the Bengal Basin delta, ${ }^{2,3,57}$ and Zheng et al. ${ }^{89}$ suggested that the concentration of mobilizable As in the sediment is an important variable regarding low As concentrations in the deep aquifer. Such conditions could potentially make the deep aquifer vulnerable to arsenic contamination, through drawdown of As from the shallow aquifer by deep tube wells, considering that humic-like DOM in the deep aquifer might promote As mobility to groundwater. ${ }^{8,90}$ The risk of As drawdown to deep aquifers has been addressed by various studies discussing sustainable and As-safe water supply in the Bengal Basin delta and has to be evaluated carefully depending on individual hydrogeological conditions. ${ }^{46,55,91}$ Moreover, other chemical properties of DOM, which are not directly visible from our DOM characterization might play a role regarding As mobility and should additionally be assessed to obtain a more detailed classification. For example, a previous study reported higher $\mathrm{C}: \mathrm{N}$ ratios for deep, Pleistocene aquifer samples with low As compared to shallow, Holocene aquifer samples with high As concentration. ${ }^{35}$

Our results present qualitative DOM characteristics for different aquifers and sample groups. It was possible to clearly differentiate fluorescence characteristics between SL and SH samples, supporting the 
theory that humic-like DOM is linked to As mobility under reducing conditions e.g. through electron

(a) shallow, low As (SL4)

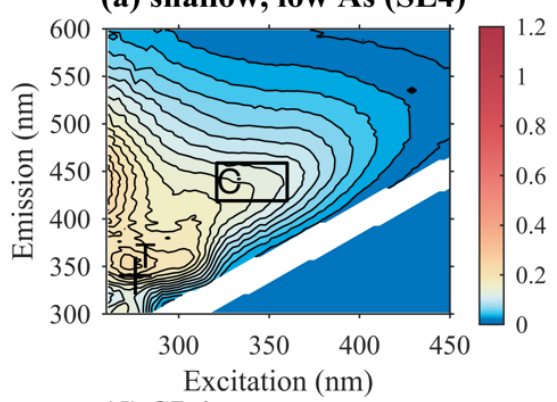

(d) SL4

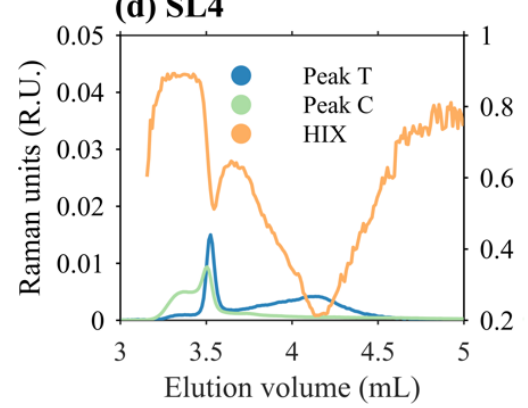

(b) shallow, high As (SH26)

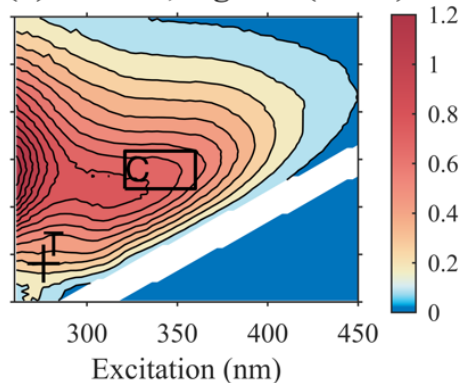

(e) $\mathrm{SH26}$

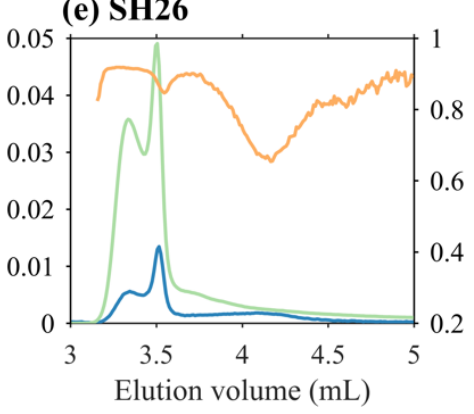

(c) deep, low As (D4)

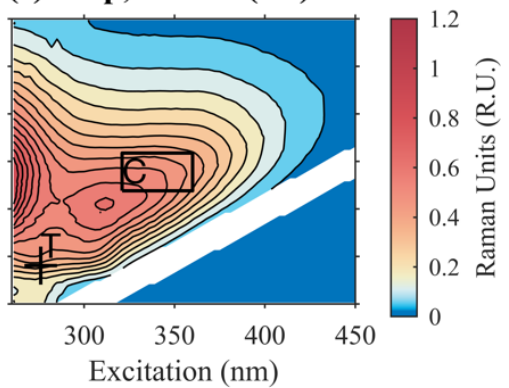

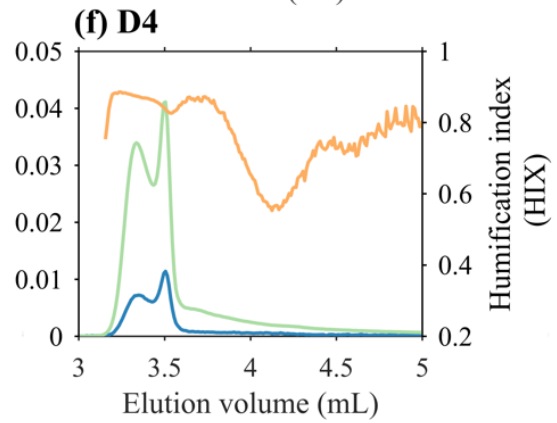

387

Figure 3: Bulk EEM characteristics of the samples SL4 (a), SH26 (b) and D4 (c), as representatives for the three analyzed groups (SL, SH, D), and their corresponding chromatograms (d-f) showing peak T, peak C and HIX.

\section{Perspectives}

The successful cross-validation between conventional PARAFAC and HPSEC-EEM-PARAFAC models offers the opportunity to carry out stable data analysis on relatively small datasets, effectually eliminating the barrier typically associated with field sampling (related to number of samples taken), and potentially opening new areas for research related to contaminated groundwater and DOM composition. Additional studies similar to Liu et al., ${ }^{28}$ are now necessary, where HPSEC-fluorescence can be coupled to ICP-MS to investigate direct interactions between DOM and metals such as As, Fe, and $\mathrm{Mn}$. If such direct interactions exist, this would reveal which metals associate with which organic 
matter size fractions. In addition, respective UV spectroscopic properties of the relevant organic matter size fractions could be characterized.

To better understand the relationships between fluorescence, DOM characteristics and arsenic mobility, batch experiments should be conducted based on aquifer sediments collected preferably from areas with well-characterized hydrology and geology. Besides the As content of the sediment, specific redox kinetics and microbial processes, as well as stoichiometry and chemical composition should be further investigated. ${ }^{35}$ This is of special interest for assessing the potential vulnerability of the deep, Pleistocene aquifer to As mobilization, which is an important clean source of drinking water in the region.

\section{Acknowledgements}

This work was conducted as part of the project 'Resilience in North and South 24 Parganas, West Bengal - Preparedness for future water-related disasters (2014-2017)', a project driven by UBU (Danish Association for Sustainable Development) and funded by CISU (civilsamfund i udvikling) (14-1461SP-apr). Field work in India was additionally supported by the organisation Joygopalpur Gram Vikash Kendra (JGVK); a special thanks goes to their daughter organisation KTT which supported the collection of field data at the study site. Laboratory work was partly funded by a Danish Council for Independent Research-Natural Sciences Grant (DFF-1323-00336 363) and Nordic5Tech collaborative funding (Technical University of Denmark).

\section{Associated Content}

\section{Supporting Information}

Supplementary Methods regarding, investigation strategy and sampling, batch experiments and HPSECEEM spectroscopy. Supplementary Figures: mapping plan (ArcGIS maps) (Fig. S1-S2), sum of squared errors for the one-sample approach (Fig. S3), bulk PARAFAC model (Fig. S4), bulk EEMS for all samples (Fig. S5-S7), chromatograms (Fig. S8-S9), batch experiments (Fig. S10-S11). Supplementary 
420 Tables: groundwater and fluorescence characteristics (Table S1-S2), chromatographic positions of peak 421 maxima for peak $\mathrm{T}$ and peak $\mathrm{C}$ (Table S3). The supporting information is available free of charge at 422 https://pubs.acs.org/.

423 


\section{References}

425

426

427

428

(1) Dhar, R.; Biswas, B.; Samanta, G.; Mandal, B.; Chakraborti, D.; Roy, S.; Jafa, A.; Islam, A.; Ara, G.; Kabir, S.; Khan, A. W.; Ahmed, S. A.; Hadi, S. A. Groundwater Arsenic Calamity in Bangaldesh. Curr. Sci. 1997, 73 (1), 48-59.

(2) McArthur, J. M.; Ravenscroft, P.; Safiulla, S.; Thirlwall, M. F.; Holloway, R. Arsenic in Groundwater: Testing Pollution Mechanisms for Sedimentary Aquifers in Bangladesh. Water Resour. Res. 2001, 37 (1), 109-117.

(3) Dowling, C. B.; Poreda, R. J.; Basu, A. R.; Peters, S. L.; Aggarwal, P. K. Geochemical Study of Arsenic Release Mechanisms in the Bengal Basin Groundwater. Water Resour. Res. 2002, 38 (9), 12-18.

(4) Chakraborti, D.; Das, B.; Rahman, M. M.; Chowdhury, U. K.; Biswas, B.; Goswami, A. B.; Nayak, B.; Pal, A.; Sengupta, M. K.; Ahamed, S.; Hossain, A.; Basu G.; Roychowdhury T.; Das D. Status of Groundwater Arsenic Contamination in the State of West Bengal, India: A 20-Year Study Report. Mol. Nutr. Food Res. 2009, 53 (5), 542-551.

(5) Fendorf, S.; Michael, H. A. Spatial and Temporal Variations of Groundwater Arsenic in South and Southeast Asia. Science (80-. ). 2010, 328 (May).

(6) Flanagan, S. V.; Johnston, R. B.; Zheng, Y. Arsenic in Tube Well Water in Bangladesh: Health and Economic Impacts and Implications for Arsenic Mitigation. Bull. World Health Organ. 2012, 90 (11), 839-846.

(7) Sankar, M. S.; Vega, M. A.; Defoe, P. P.; Kibria, M. G.; Ford, S.; Telfeyan, K.; Neal, A.; Mohajerin, T. J.; Hettiarachchi, G. M.; Barua, S.; Hobson, C.; Johannesson, K.; Datta, S. Elevated Arsenic and Manganese in Groundwaters of Murshidabad, West Bengal, India. Sci. Total Environ. 2014, 488-489 (1), 570-579.

(8) Kulkarni, H. V.; Mladenov, N.; Johannesson, K. H.; Datta, S. Contrasting Dissolved Organic 
Matter Quality in Groundwater in Holocene and Pleistocene Aquifers and Implications for Influencing Arsenic Mobility. Appl. Geochemistry 2017, 77, 194-205.

450

(9) McArthur, J. M.; Banerjee, D. M.; Hudson-Edwards, K. A.; Mishra, R.; Purohit, R.; Ravenscroft, P.; Cronin, A.; Howarth, R. J.; Chatterjee, A.; Talukder, T.; Lowry, D.; Houghton, S.; Chadha, D. K. Natural Organic Matter in Sedimentary Basins and Its Relation to Arsenic in Anoxic Ground Water: The Example of West Bengal and Its Worldwide Implications. Appl. Geochemistry 2004, 19 (8), 1255-1293.

(10) Sharma, P.; Rolle, M.; Kocar, B. D.; Fendorf, S.; Kapppler, A. Influence of Natural Organic Matter on As Transport and Retention. Environ. Sci. Technol. 2010, 45 (2), 546-553.

(11) Nickson, R. T.; Mcarthur, J. M.; Ravenscroft, P.; Burgess, W. G.; Ahmed, K. M. Mechanism of Arsenic Release to Groundwater, Bangladesh and West Bengal. Appl. Geochemistry 2000, 15, 403-413.

(12) Neidhardt, H.; Berner, Z. A.; Freikowski, D.; Biswas, A.; Majumder, S.; Winter, J.; Gallert, C.; Chatterjee, D.; Norra, S. Organic Carbon Induced Mobilization of Iron and Manganese in a West Bengal Aquifer and the Muted Response of Groundwater Arsenic Concentrations. Chem. Geol. 2014, 367, 51-62.

(13) Cozzarelli, I. M.; Schreiber, M. E.; Erickson, M. L.; Ziegler, B. A. Arsenic Cycling in Hydrocarbon Plumes: Secondary Effects of Natural Attenuation. Groundwater 2016, 54 (1), 3545.

(14) Sengupta, S.; Mcarthur, J. M.; Sarkar, A.; Leng, M. J.; Ravenscroft, P.; Howarth, R. J.; Banerjee, D. M. Do Ponds Cause Arsenic-Pollution of Groundwater in the Bengal Basin? An Answer from West Bengal. Environ. Sci. Technol. 2008, 42 (14), 5156-5164.

(15) Datta, S.; Neal, A. W.; Mohajerin, T. J.; Ocheltree, T.; Rosenheim, B. E.; White, C. D.; Johannesson, K. H. Perennial Ponds Are Not an Important Source of Water or Dissolved Organic 
Matter to Groundwaters with High Arsenic Concentrations in West Bengal, India. Geophys. Res. Lett. 2011, $38(20), 1-5$.

(16) Neumann, R. B.; Pracht, L. E.; Polizzotto, M. L.; Badruzzaman, A. B. M.; Ali, M. A. Biodegradable Organic Carbon in Sediments of an Arsenic-Contaminated Aquifer in Bangladesh. Environ. Sci. Technol. Lett. 2014, 1 (4), 221-225.

(17) Harvey, C. F.; Ashfaque, K. N.; Yu, W.; Badruzzaman, A. B. M.; Ali, M. A.; Oates, P. M.; Michael, H. A.; Neumann, R. B.; Beckie, R.; Islam, S.; Ahmed, M. F. Groundwater Dynamics and Arsenic Contamination in Bangladesh. Chem. Geol. 2006, 228 (1-3 SPEC. ISS.), 112-136.

(18) Neumann, R. B.; Ashfaque, K. N.; Badruzzaman, A. B. M.; Ashraf Ali, M.; Shoemaker, J. K.; Harvey, C. F. Anthropogenic Influences on Groundwater Arsenic Concentrations in Bangladesh. Nat. Geosci. 2010, 3 (1), 46-52.

(19) Lawson, M.; Polya, D. A.; Boyce, A. J.; Bryant, C.; Ballentine, C. J. Tracing Organic Matter Composition and Distribution and Its Role on Arsenic Release in Shallow Cambodian Groundwaters. Geochim. Cosmochim. Acta 2016, 178, 160-177.

(20) McArthur, J. M.; Ravenscroft, P.; Sracek, O. Aquifer Arsenic Source. Nat. Geosci. 2011, 4 (10), $655-656$.

(21) Eiche, E.; Berg, M.; Hönig, S. M.; Neumann, T.; Lan, V. M.; Pham, T. K. T.; Pham, H. V. Origin and Availability of Organic Matter Leading to Arsenic Mobilisation in Aquifers of the Red River Delta, Vietnam. Appl. Geochemistry 2017, 77, 184-193.

(22) Wang, S.; Mulligan, C. N. Effect of Natural Organic Matter on Arsenic Release from Soils and Sediments into Groundwater. Environ. Geochem. Health 2006, 28 (3), 197-214.

(23) Mladenov, N.; Zhengg, Y.; Miller, M. P.; Nemergut, D. M.; Legg, T.; Simone, B.; Hageman, C.; Rahman, M. M.; Ahmed, K. M.; McKnight, D. M. Dissolved Organic Matter Sources and Consequences for Iron and Arsenic Mobilization in Bangladesh Aquifers. Environ. Sci. Technol. 
2010, 44 (May 2016), 123-128.

(24) Mladenov, N.; Zheng, Y.; Simone, B.; Bilinski, T. M.; McKnight, D. M.; Nemergut, D.; Radloff, K. A.; Rahman, M. M.; Ahmed, K. M. Dissolved Organic Matter Quality in a Shallow Aquifer of Bangladesh: Implications for Arsenic Mobility. Environ. Sci. Technol. 2015, 49 (18), 1081510824.

(25) Kulkarni, H. V.; Mladenov, N.; McKnight, D. M.; Zheng, Y.; Kirk, M. F.; Nemergut, D. R. Dissolved Fulvic Acids from a High Arsenic Aquifer Shuttle Electrons to Enhance Microbial Iron Reduction. Sci. Total Environ. 2018, 615, 1390-1395.

(26) Bauer, M.; Blodau, C. Mobilization of Arsenic by Dissolved Organic Matter from Iron Oxides, Soils and Sediments. Sci. Total Environ. 2006, 354 (2-3), 179-190.

(27) Sharma, P.; Ofner, J.; Kappler, A. Formation of Binary and Ternary Colloids and Dissolved Complexes of Organic Matter, Fe and As. Environ. Sci. Technol. 2010, 44 (12), 1-8.

(28) Liu, G.; Fernandez, A.; Cai, Y. Complexation of Arsenite with Humic Acid in the Presence of Ferric Iron. Environ. Sci. Technol. 2011, 45 (8), 3210-3216.

(29) Liang, L.; Singer, P. C. Factors Influencing the Formation and Relative Distribution of Haloacetic Acids and Trihalomethanes in Drinking Water. Environ. Sci. Technol. 2003, 37 (13), $2920-2928$.

(30) Minor, E. C.; Swenson, M. M.; Mattson, B. M.; Oyler, A. R. Structural Characterization of Dissolved Organic Matter: A Review of Current Techniques for Isolation and Analysis. Environ. Sci. Process. Impacts 2014, 16 (9), 2064-2079.

(31) Reza, A. H. M. S.; Jean, J. S.; Yang, H. J.; Lee, M. K.; Hsu, H. F.; Liu, C. C.; Lee, Y. C.; Bundschuh, J.; Lin, K. H.; Lee, C. Y. A Comparative Study on Arsenic and Humic Substances in Alluvial Aquifers of Bengal Delta Plain (NW Bangladesh), Chianan Plain (SW Taiwan) and Lanyang Plain (NE Taiwan): Implication of Arsenic Mobilization Mechanisms. Environ. 
(32) Vega, M. A.; Kulkarni, H. V.; Mladenov, N.; Johannesson, K.; Hettiarachchi, G. M.; Bhattacharya, P.; Kumar, N.; Weeks, J.; Galkaduwa, M.; Datta, S. Biogeochemical Controls on the Release and Accumulation of Mn and As in Shallow Aquifers, West Bengal, India. Front. Environ. Sci. 2017, 5 (3), 1-16.

(33) Bro, R. PARAFAC. Tutorial and Applications. Chemom. Intell. Lab. Syst. 1997, 38 (2), 149171.

(34) Stedmon, C. A.; Markager, S.; Bro, R. Tracing Dissolved Organic Matter in Aquatic

(35) Kulkarni, H. V.; Mladenov, N.; Datta, S.; Chatterjee, D. Influence of Monsoonal Recharge on

(39) Perminova, I. V.; Frimmel, F. H.; Kudryavtsev, A. V.; Kulikova, N. A.; Abbt-Braun, G.; Hesse,

(38) Amon, R.; Benner, R. Bacterial Utilization of Different Size Classes of Dissolved Organic Matter. Limnol. Oceanogr. 1996, 41 (1), 41-51.

S.; Petrosyan, V. S. Molecular Weight Characteristics of Humic Substances from Different Environments as Determined by Size Exclusion Chromatography and Their Statistical 
Evaluation. Environ. Sci. Technol. 2003, 37 (11), 2477-2485.

(40) Ravenscroft, P.; Brammer, H.; Richards, K. Arsenic Pollution: A Global Synthesis; WileyBlackwell: Oxford, U.K., 2009.

(41) Alam, M.; Alam, M. M.; Curray, J. R.; Chowdhury, M. L. R.; Gani, M. R. An Overview of the Sedimentary Geology of the Bengal Basin in Relation to the Regional Tectonic Framework and Basin-Fill History. Sediment. Geol. 2003, 155 (3-4), 179-208.

(42) Dowling, C. B.; Poreda, R. J.; Basu, A. R. The Groundwater Geochemistry of the Bengal Basin: Weathering, Chemsorption, and Trace Metal Flux to the Oceans. Geochim. Cosmochim. Acta 2003, 67 (12), 2117-2136.

(43) Mukherjee, A.; Fryar, A. E.; Thomas, W. A. Geologic, Geomorphic and Hydrologic Framework and Evolution of the Bengal Basin, India and Bangladesh. J. Asian Earth Sci. 2009, 34 (3), 227244.

(44) Harvey, C. F.; Swartz, C. H.; Badruzzaman, A. B. M.; Keon-Blute, N.; Yu, W.; Ali, M. A.; Jay, J.; Beckie, R.; Niedan, V.; Brabander, D.; Oates, P. M.; Ashfaque, K. N.; Islam, S.; Hemond, H. F.; Ahmed, M. F. Arsenic Mobility and Groundwater Extraction in Bangladesh. Science (80-. ). 2002, 298 (November), 1602-1607.

(45) Umitsu, M. Late Quaternary Sedimentary Environments and Landforms in the Ganges Delta. Sediment. Geol. 1993, 83 (3-4), 177-186.

(46) Burgess, W. G.; Hoque, M. A.; Michael, H. A.; Voss, C. I.; Breit, G. N.; Ahmed, K. M. Vulnerability of Deep Groundwater in the Bengal Aquifer System to Contamination by Arsenic. Nat. Geosci. 2010, 3 (February), 83-87.

(47) McArthur, J. M.; Ravenscroft, P.; Banerjee, D. M.; Milsom, J.; Hudson-Edwards, K. A.; Sengupta, S.; Bristow, C.; Sarkar, A.; Tonkin, S.; Purohit, R. How Paleosols Influence Groundwater Flow and Arsenic Pollution: A Model from the Bengal Basin and Its Worldwide 
Implication. Water Resour. Res. 2008, 44 (11), 1-30.

(48) Goodbred, S. L.; Kuehl, S. A. The Significance of Large Sediment Supply, Active Tectonism, and Eustasy on Margin Sequence Development: Late Quaternary Stratigraphy and Evolution of the Ganges-Brahmaputra Delta. Sediment. Geol. 2000, 133 (3-4), 227-248.

(49) Ghosal, U.; Sikdar, P. K.; McArthur, J. M. Palaeosol Control of Arsenic Pollution: The Bengal Basin in West Bengal, India. Groundwater 2015, 53 (4), 588-599.

(50) Mukherjee, A.; Fryar, A. E.; Howell, P. D. Regional Hydrostratigraphy and Groundwater Flow Modeling in the Arsenic-Affected Areas of the Western Bengal Basin, West Bengal, India. Hydrogeol. J. 2007, 15 (7), 1397-1418.

(51) Talukdar, T.; Ghosh, A. K.; Srivastava, K. K. Arsenic in Ground Water of North 24 Parganas District, West Bengal. Bhujal News Quaterly J. 2009, No. April-Sept.

(52) International Water Management Institute. Hydrogeology of the Eastern Ganges Basin: An Overview; 157; Colombo, 2013.

(53) Neidhardt, H.; Biswas, A.; Freikowski, D.; Majumder, S.; Chatterjee, D.; Berner, Z. A. Reconstructing the Sedimentation History of the Bengal Delta Plain by Means of Geochemical and Stable Isotopic Data. Appl. Geochemistry 2013, 36, 70-82.

(54) Biswas, A.; Neidhardt, H.; Kundu, A. K.; Halder, D.; Chatterjee, D.; Berner, Z.; Jacks, G.; Bhattacharya, P. Spatial, Vertical and Temporal Variation of Arsenic in Shallow Aquifers of the Bengal Basin: Controlling Geochemical Processes. Chem. Geol. 2014, 387, 157-169.

(55) Michael, H. A.; Voss, C. I. Evaluation of the Sustainability of Deep Groundwater as an ArsenicSafe Resource in the Bengal Basin. Proc. Natl. Acad. Sci. 2008, 105 (25), 8531-8536.

(56) U.S. Geological Survey. Compositional Data for Bengal Delta Sediment Collected from Boreholes at Srirampur, Bangladesh; Reston, 2006. 
(57)

DPHE. Arsenic Contamination of Groundwater in Bangladesh, BGS Technical Report, WC/00/19; Kinniburgh, D. G., Smedley, P. L., Eds.; British Geological Survey: Keyworth, 2001.

(58) Lowers, H. A.; Breit, G. N.; Foster, A. L.; Whitney, J.; Yount, J.; Uddin, M. N.; Muneem, A. A. Arsenic Incorporation into Authigenic Pyrite, Bengal Basin Sediment, Bangladesh. Geochim. Cosmochim. Acta 2007, 71 (11), 2699-2717.

(59) Fakhreddine, S.; Lee, J.; Kitanidis, P. K.; Fendorf, S.; Rolle, M. Imaging Geochemical Heterogeneities Using Inverse Reactive Transport Modeling: An Example Relevant for Characterizing Arsenic Mobilization and Distribution. Adv. Water Resour. 2016, 88, 186-197.

(60) Stollenwerk, K. G.; Breit, G. N.; Welch, A. H.; Yount, J. C.; Whitney, J. W.; Foster, A. L.; Uddin, M. N.; Majumder, R. K.; Ahmed, N. Arsenic Attenuation by Oxidized Aquifer Sediments in Bangladesh. Sci. Total Environ. 2007, 379 (2-3), 133-150.

(61) Chen, H.; Kenny, J. E. A Study of PH Effects on Humic Substances Using Chemometric Analysis of Excitation-Emission Matrices. Ann. Environ. Sci. 2007, 1, 1-9.

(62) Schneider-Zapp, K.; Salter, M. E.; Mann, P. J.; Upstill-Goddard, R. C. Technical Note: Comparison of Storage Strategies of Sea Surface Microlayer Samples. Biogeosciences 2013, 10 (7), 4927-4936.

(63) Weishaar, J. L.; Aiken, G. R.; Bergamaschi, B. A.; Fram, M. S.; Fujii, R.; Mopper, K. Evaluation of Specific Ultraviolet Absorbance as an Indicator of the Chemical Composition and Reactivity of Dissolved Organic Carbon. Environ. Sci. Technol. 2003, 37 (20), 4702-4708.

(64) Murphy, K. R.; Stedmon, C. A.; Graeber, D.; Bro, R. Fluorescence Spectroscopy and Multi-Way Techniques. PARAFAC. Anal. Methods 2013, 5 (23), 6557-6882.

(65) Kothawala, D. N.; Murphy, K. R.; Stedmon, C. A.; Weyhenmeyer, G. A.; Tranvik, L. J. Inner Filter Correction of Dissolved Organic Matter Fluorescence. Limnol. Oceanogr. Methods 2013, 11 (DEC), 616-630. 
615 (66) Ohno, T. Fluorescence Inner-Filtering Correction for Determining the Humification Index of Dissolved Organic Matter. Environ. Sci. Technol. 2002, 36 (4), 742-746.

(67) McKnight, D. M.; Boyer, E. W.; Westerhoff, P. K.; Doran, P. T.; Kulbe, T.; Andersen, D. T. Spectrofluorometric Characterization of Dissolved Organic Matter for Indication of Precursor Organic Material and Aromaticity. Limnol. Oceanogr. 2001, 46 (1), 38-48.

620 621

(68) Parlanti, E.; Wörz, K.; Geoffroy, L.; Lamotte, M. Dissolved Organic Matter Fluorescence Spectroscopy as a Tool to Estimate Biological Activity in a Coastal Zone Submitted to Anthropogenic Inputs. Org. Geochem. 2000, 31, 1765-1781.

(69) Coble, P. G.; Castillo, C. E. Del; Avril, B. Distribution and Optical Properties of CDOM in the Arabian Sea during the 1995 Southwest Monsoon. Deep. Res. Part II 1998, 45, 2195-2223.

(70) Coble, P. G. Marine Optical Biogeochemistry: The Chemistry of Ocean Color. Chem. Rev. 2007, $107(2), 402-418$.

(71) Tucker, L. R. A Method for Synthesis of Factor Analysis Studies. Pers. Res. Sect. Rep. No. 984, Dep. Army 1951.

(72) Lorenzo-Seva, U.; ten Berge, J. M. F. Tucker's Congruence Coefficient as a Meaningful Index of Factor Similarity. Methodology 2006, 2 (2), 57-64.

(73) Ramette, A. Multivariate Analyses in Microbial Ecology. FEMS Microbiol. Ecol. 2007, 62 (2), $142-160$.

(74) Fellman, J. B.; Hood, E.; Spencer, R. G. M. Fluorescence Spectroscopy Opens New Windows into Dissolved Organic Matter Dynamics in Freshwater Ecosystems: A Review. Limnol. Oceanogr. 2010, 55 (6), 2452-2462.

(75) Murphy, K. R.; Butler, K. D.; Spencer, R. G. M.; Stedmon, C. A.; Boehme, J. R.; Aiken, G. R. Measurement of Dissolved Organic Matter Fluorescence in Aquatic Environments: An 
Interlaboratory Comparison. Environ. Sci. Technol. 2010, 44 (24), 9405-9412.

(76) Murphy, K. R.; Stedmon, C. A.; Wenig, P.; Bro, R. OpenFluor- An Online Spectral Library of Auto-Fluorescence by Organic Compounds in the Environment. Anal. Methods 2014, 6 (3), 658661.

(77) Murphy, K. R.; Stedmon, C. A.; Waite, T. D.; Ruiz, G. M. Distinguishing between Terrestrial and Autochthonous Organic Matter Sources in Marine Environments Using Fluorescence Spectroscopy. Mar. Chem. 2008, 108 (1-2), 40-58.

(78) Cawley, K. M.; Butler, K. D.; Aiken, G. R.; Larsen, L. G.; Huntington, T. G.; McKnight, D. M. Identifying Fluorescent Pulp Mill Effluent in the Gulf of Maine and Its Watershed. Mar. Pollut. Bull. 2012, 64 (8), 1678-1687.

(79) Murphy, K. R.; Hambly, A.; Singh, S.; Henderson, R. K.; Baker, A.; Stuetz, R.; Khan, S. J. Organic Matter Fluorescence in Municipal Water Recycling Schemes: Toward a Unified PARAFAC Model. Environ. Sci. Technol. 2011, 45 (7), 2909-2916.

(80) Stedmon, C. A.; Seredyńska-Sobecka, B.; Boe-Hansen, R.; Le Tallec, N.; Waul, C. K.; Arvin, E. A Potential Approach for Monitoring Drinking Water Quality from Groundwater Systems Using Organic Matter Fluorescence as an Early Warning for Contamination Events. Water Res. 2011, 45 (18), 6030-6038.

(81) Patriarca, C.; Bergquist, J.; Sjöberg, P. J. R.; Tranvik, L.; Hawkes, J. A. Online HPLC-ESIHRMS Method for the Analysis and Comparison of Different Dissolved Organic Matter Samples. Environ. Sci. Technol. 2018, 52, 2091-2099.

(82) Sandron, S.; Rojas, A.; Wilson, R.; Davies, N. W.; Haddad, P. R.; Shellie, R. A.; Nesterenko, P. N.; Kelleher, B. P.; Paull, B. Chromatographic Methods for the Isolation, Separation and Characterisation of Dissolved Organic Matter. Environ. Sci. Process. Impacts 2015, 17 (9), $1531-1567$. 
662 (83) Mukherjee, A. Deeper Groundwater Flow and Chemistry in the Arsenic Affected Western Bengal Basin, West Bengal, India, University of Kentucky, 2006.

664

665

666

667

668

669

670

671

672

673

674

675

676

677

678

679

680

681

682

683

684

685

(84) Smedley, P. L.; Appelo, T. Sources and Distribution of Arsenic in Groundwater and Aquifers. In Arsenic in Groundwater - A World Problem; Netherlands National Committee of the IAH, 2006; pp 4-32.

(85) Stute, M.; Zheng, Y.; Schlosser, P.; Horneman, A.; Dhar, R. K.; Datta, S.; Hoque, M. A.; Seddique, A. A.; Shamsudduha, M.; Ahmed, K. M.; van Geen, A. Hydrological Control of As Concentrations in Bangladesh Groundwater. Water Resour. Res. 2007, 43, 1-11.

(86) Klump, S.; Kipfer, R.; Cirpka, O. A.; Harvey, C. F.; Brennwald, M. S.; Ashfaque, K. N.; Badruzzaman, A. B. M.; Hug, S. J.; Imboden, D. M. Groundwater Dynamics and Arsenic Mobilization in Bangladesh Assessed Using Noble Gases and Tritium. Environ. Sci. Technol. 2006, 40 (1), 243-250.

(87) Poulin, B. A.; Ryan, J. N.; Aiken, G. R. Effects of Iron on Optical Properties of Dissolved Organic Matter. Environ. Sci. Technol. 2014, No. 48, 10098-10106.

(88) Hering, J. G.; Kneebone, P. E. Biogeochemical Controls on Arsenic Occurrence and Mobility in Water Supplies. In Environmental Chemistry of Arsenic; Frankenberger, W. T., Ed.; Marcel Dekker, 2002.

(89) Zheng, Y.; van Geen, A.; Stute, M.; Dhar, R.; Mo, Z.; Cheng, Z.; Horneman, A.; Gavrieli, I.; Simpson, H. J.; Versteeg, R.; Steckler, M.; Grazioli-Venier, A.; Goodbred, S.; Shahnewaz, M.; Shamsudduha, M.; Hoque, M. A.; Ahmed, K. M. Geochemical and Hydrogeological Contrasts between Shallow and Deeper Aquifers in Two Villages of Araihazar, Bangladesh: Implications for Deeper Aquifers as Drinking Water Sources. Geochim. Cosmochim. Acta 2005, 69 (22), $5203-5218$.

(90) Kulkarni, H. V. Biogeochemical Interactions of Natural Organic Matter with Arsenic in 
686

687 688 689 690

Groundwater, Kansas State University, 2016.

(91) Ravenscroft, P.; McArthur, J. M.; Hoque, M. A. Stable Groundwater Quality in Deep Aquifers of Southern Bangladesh: The Case against Sustainable Abstraction. Sci. Total Environ. 2013, 454-455, 627-638. 